\title{
Towards a Theoretical Model Relating Product Development Strategy, Market Adoption and Firm Performance: A Research Agenda
}

\author{
Sheila C. Koks ${ }^{1}$ \& James. M. Kilika ${ }^{1}$ \\ ${ }^{1}$ Department of Business Administration, Kenyatta University, Nairobi, Kenya \\ Correspondence: James. M. Kilika, PhD, Lecturer, Department of Business Administration, Kenyatta University, \\ Nairobi, Kenya. \\ Received: February 2, 2016 \\ Accepted: February 17, $2016 \quad$ Online Published: February 19, 2016 \\ doi:10.5430/jms.v7n1p90 \\ URL: http://dx.doi.org/10.5430/jms.v7n1p90
}

\begin{abstract}
There has been a marked increased attention to the concept of product development strategy and firm performance. The focus has been undertaken to respond to the growing interest at both local and international business on the role of product development strategy as the bloodline for business growth. Even though this relationship combined with that of innovation may lead to companies gaining competitive advantage, the previous studies have assumed a simple direct relationship and have failed to integrate other contextual characteristics of the market as espoused by some of the theoretical arguments that underpin the relationship. Sustained firm performance may result when a firm repeatedly introduces product development strategy that service customers ever changing needs. The paper responds to these concerns by proposing a theoretical perspective that considers the direct relationship while including the role of the market characteristics of adoption. The emergent theoretical model is proposed and various constructs and their relationship suggested.
\end{abstract}

Keywords: product development strategy, market adoption, firm performance

\section{Introduction}

The concept of product development strategy has grown and is often viewed as the main tool to increase firm performance. Product development strategy has been considered the bloodline for growth for international companies. Product development strategy coupled with innovation allows companies to gain competitive advantage, attract new customers, retain existing customers and strengthen their ties with their distribution networks (Kotler \& Keller, 2006). Both theoretical literature and extant empirical research emphasize the relationship between product development strategy and firm performance (Coopen \& Kleinschmidt, 1990).

Product development strategy may involve modification of an existing product or its presentation, or formulation of an entirely new product that satisfies a newly defined customer want or market niche. Ansoff's (1957) approach to the product development (PD) process was based on the broad concept of growth strategy which is operationalized using three strategies: Integrative growth, intensive growth and diversification growth. The PD strategy falls under intensive growth strategy. The Ansoff matrix that operationalizes the intensive growth strategy considers the firms product and markets in their current and new situations.

Product development strategy is the process of designing, creating and marketing new products or services to benefit customers (Ansoff, 1957). Sometimes referred to as new product development, the process is focused on developing systematic methods for guiding the processes involved in getting a new product to the market. This is in response to the fact that the life cycle of products is decreasing every year and customers demand on the other hand is increasing dramatically. With the need to respond quickly to customer requirements, increased complexity of product design and rapidly changing technology, selecting the right set of PD strategy is critical to the long term success of a firm, hence the need to link product development strategy with market adoption process in the path to a firms performance. The aspect of market adoption is a cognitive process through which all the consumers pass before actually purchasing a product. It has been presented as a sequence of stages whose occurrence and outcome will determine the success of a new product development strategy in the market. The potential value of its contribution towards the success of the strategy and the market requires understanding not only at the theoretical, but also empirical level. 
Even though the previous studies have modelled the relationship between product development strategy and firm performance as a linear direct one, the relevant theories that discuss this phenomenon indicate that such a relationship is more rigorous opening possibilities of mediating and moderating factors. This paper introduces the role of market adoption into this relationship.

The purpose of this paper is to propose a theoretical model relating product development strategy and performance while providing for the role of market adoption process. Thus the study has three objectives. First it reviews the relevant theories to explaining the phenomenon between product development strategy and firm performance. Secondly the paper looks the relevant constructs in phenomenon. Thirdly the paper proposes a theoretical model indicating the roles and the relationship among the constructs.

\section{Theoretical Review}

The phenomenon of product development strategy in relation with firm performance is one that is of strategic importance to organizations. One of the defining attributes of strategic thinking is that of the role of external environment in the firm's strategic behaviour (Frank, 2004). Adoption of this strategy as an aspect of firm strategic behaviour requires explanation by a multifaceted theoretical base that addresses the firm's internal processes/systems and the external context where the strategy is applied. This paper adopted a multidisciplinary perspective founded on theoretical works that are relevant to the phenomenon of product development and firm performance. The paper relied on Igor Ansoff matrix model, Diffusion of Innovation theory and the Resource Based View (RBV) of the firm.

The Ansoff Matrix model is a strategic planning tool that provides a framework to help executives, senior managers, and marketer's device strategies for future growth. It is named after Russian American Scholar Igor Ansoff, who came up with the concept. The Ansoff Growth matrix is considered to be an important strategic planning tool that helps a business determine its product and market growth strategy. This theory aids in explaining how the concept of product development strategy is borne in any organization.

The Ansoff matrix (1957) as a business technique provides a framework enabling growth opportunities to be identified as it helps firms to device the strategies they adopt and each of these growth options draws on both internal and external influences. The matrix offers a structured way to assess potential strategies for growth. The four strategies are: market penetration, product development, market development and diversification. Market penetration involves selling more established products into existing markets, often by increased promotion or price reductions or better routes to market, for example online. Product development involves developing new products or services and placing them into existing markets. Market development entails taking existing products or services and selling them in new markets. Diversification involves developing new products and putting them into new markets at the same time. Diversification is considered the most risky strategy. This is because the business is expanding into areas outside its core activities and experience as well as targeting.

Even though the Ansoff growth strategy helps companies come up with new products and new target markets, research however shows that consumers differ in how quickly they decide to adopt (buy) a product after they are introduced in the market. A relevant theoretical approach that responds to this weakness is that of Everett Rogers called Diffusion of innovation. Everett M. Rogers' theory on Diffusion of Innovation, explores what type of person adopts products at different stages of the product life cycle. Under Rogers' Diffusion of Innovation, a product will encounter five types of purchasers as it moves through its life cycle. There is need to link growth strategy and diffusion of innovation phenomenon. Diffusion of innovations is a theory (Rogers, 1985) that seeks to explain how, why, and at what rate new ideas and technology spread through cultures. In the book Diffusion of Innovations, Rogers suggests a total of five categories of adopters in order to standardize the usage of adopter categories in diffusion research. The adoption of an innovation follows an $\mathrm{S}$ curve when plotted over a length of time. Rogers argues that diffusion is the process by which an innovation is communicated through certain channels over time among the participants in a social system.

The categories of adopters include innovators, early adopters, early majority, late majority and laggards; Innovators are willing to take risks, have the highest social status, have financial liquidity, are social and have closest contact to scientific sources and interaction with other innovators. Their risk tolerance allows them to adopt technologies that may ultimately fail. Financial resources help absorb these failures. The early adopters are individuals who have the highest degree of opinion leadership among the adopter categories. Early adopters have a higher social status, financial liquidity, advanced education and are more socially forward than late adopters. They are more discreet in 
adoption choices than innovators. They use judicious choice of adoption to help them maintain a central communication position. The Early Majority adopt an innovation after a varying degree of time that is significantly longer than the innovators and early adopters. Early Majority have above average social status, contact with early adopters and seldom hold positions of opinion leadership in a system. The Late Majority adopt to an innovation after the average participant. These individuals approach an innovation with a high degree of skepticism and after the majority of society has adopted the innovation. Late Majority are typically skeptical about an innovation, have below average social status, and little financial liquidity, in contact with others in late majority and early majority and little opinion leadership. The Laggards are the last to adopt an innovation. Unlike some of the previous categories, individuals in this category show little to no opinion leadership. These individuals typically have an aversion to change-agents. Laggards typically tend to be focused on "traditions", lowest social status, lowest financial liquidity, oldest among adopters, and in contact with only family and close friends. The Diffusion of innovation theory therefore is useful in understanding the concept of market adoption characteristics which is seen as the link between product development strategy and firm performance.

The product development process needs complements from the resource based perspective that is gaining prominence within the strategy literature. This helps define the precise nature of the underlying firm capabilities that support product development strategy. The Resource-based view perceives a firm as an aggregation of resources which are translated by management into strengths and weaknesses of the firm (Barner, Wright \& Ketchen, 2001). RBV hold that companies gain sustainable competitive advantages by deploying valuable resources and capabilities that are inelastic in supply. This perspective contends that a firms competitive advantage is due to endownment of strategic resources that are valuable, rare costly to imitate and costly to substitute. It assumes that organizations must be successful in obtaining and managing valued resources in order to be effective. RBV approach invokes the concept of competitive advantage to explain firm performance (Barner, Wright \& Ketchen, 2001).

Drawing from the resource based view of the firm (Barney, 2001), the study posits that environment performance and economic performance are linked. This paper links the underlying economics of the resource based view of competitive advantage and its relation to product development strategy and eventually its relation to firm performance. RBV holds and states that sustained competitive advantage can be achieved more easily by exploiting internal rather than external factors and product development strategy is one way to achieve this competitive advantage through development of new products to target the already existing markets.

The success and continuous sustainability of PD strategy is seen as a source of competitive advantage for many companies which want to survive in an ever changing environment and in so doing they need to have resources which are rare, valuable, inimitable and non-substitutable in nature. The characteristics mentioned are individually necessary in product development strategy but not sufficient for competitive advantage. PD strategy must be linked with markets in order to have a comprehensive link to firm performance objective.

\section{Emerging Issues}

The above review highlights a number of issues that empirical work needs to address. First, the reviews indicate that perhaps no activity is more vital to growing a company than the development and launch of successful new product offerings (Kirshnan, Ulrich \&Karl, 2001). However real life experience shows that the success rate of new products has been very disappointing, despite the use of increasingly sophisticated research and testing approaches. The new-product problems faced by strategic managers could be the result of not integrating characteristics of the markets into the product development process. Secondly given the complex, disruptive, fragmented nature of the markets characterised by diverse technological changes, competitor's analysis and firm's resources and capabilities, senior management should recognize the need for a formalized, consistent, and comprehensive framework to analyze the firm's strategic posture. Therefore modern assessment tools such as that proposed in Ansoff's seminal contributions to strategic diagnosis, should focus on identifying and enhancing the firm's strategic performance potential through the analysis of the industry's environmental turbulence level relative to the firm's aggressiveness and responsive capability.

Thirdly, extant research supports the necessity of integrating the elements of normative strategic planning, external environment, and the strategic choice perspectives in models of the strategic decision process (Bourgeois, 1984; Eisenhardt \& Zbaracki, 1992; Glaister, 2008; Hrebiniak, Joyce, \& Snow, 1988). Product development strategy should therefore not be considered a single panacea but instead should be linked to other concepts, procedures, tools and practices intended to assist the firm to achieve firm performance. For example Ansoff's strategic diagnosis and 
positional matrices are invaluable strategic tools for firms, even though they are positional analyses singularly reflecting a blind spot in modeling the firm's future strategic performance potential, as neither considers the interactions of the other strategies. Igor Ansoff's matrix contributions to strategic diagnosis primarily focused on identifying and enhancing the firm's strategic performance potential through the analysis of the industry's environmental turbulence level relative to the firm's aggressiveness and responsiveness of capability. There is need to relook at a combined diagnosis including and not limited to, Strengths, Weaknesses, Opportunities, Threats (SWOT), Resource-Based View and market adoption process as useful methodologies to aid in the planning process all of which are complex and involve multiple managerial perspectives. Igor Ansoff theories are interlinked or dependent on other theories, for example the Diffusion of Innovation theory.

Diffusion of innovation theory describes the market characteristics and this is seen as a link between product development strategy and firm performance. Diffusion of innovation theory (Rogers, 2005) describes the process through which new innovations and ideas become diffused and adopted within wider socialnetworks. Diffusion is difficult to quantify because humans and human networks are complex. It is extremely difficult, if not impossible, to measure what exactly causes adoption of innovation. Diffusion theories can never account for all variables, and therefore there is need to integrate the theory with other variables in order to measure its effectiveness. Firm performance might be one of the most effective variables for measuring and quantifying diffusion.

The above issues considered against some empirical studies indicate that product development strategy needs to be approached as a component of firm strategic behaviour that should be theoretically supported from a multiple theoretical base in understanding its relative contribution to firm performance. Academia has produced a large amount of empirical evidence concerning the factors that enhance or reduce the chances of new product success. An interesting aspect of the identified success factors is the degree to which companies are able to control them. For example, Cooper \& Kleinschmidt (1987) concluded that "controllable variables, rather than situational or environment variables, are the dominant factors in success of a product development strategy.

Analysis of some of the empirical attempts indicates that various studies have been conducted on this subject matter. For example Ngumi (2013), in an attempt to explain the effects of bank innovations on financial performance established that bank innovations have some positive influence on bank performance. The study was conceptualized using ICT form of innovation in relation to bank performance. Even though the relationship seems clear, the conceptualization however faces limitations in that aspects of the market were not included in the study and the innovations were not approached from a viewpoint of strategy. In addition the moderating influence of the context of the innovation was not assessed. Sook, May and Ketchen (2014), who sought to find out the impact of new product development on organizational performance found that four types of new product development factors, namely firm image, brand strength, product innovativeness and product quality are positively related to new product performance. The study conceptualized four factors in a product development i.e. firm image, brand strength, product innovativeness and product quality which are aspects surrounding already existing product development. However the aspects of NPD strategy were not included in this study. Andrea and Pamela (2014)'s study aimed to explore the relationship between new product development strategy implementation and performance and they found that there was a significant relationship between New product development (NPD) strategy implementation and new venture performance. Even though this study portrayed a direct relationship, product development strategy and firm performance may not have a straight forward relationship. There is a possibility of a moderating factor in linking the two variables hence need to link the two variables using market adoption characteristics.

According to Čok, Fain, Vukašinovic and Žavbi (2015) who attempted to put forward and test an integrated research protocol for study of R\& D in product development strategy concluded that marketing interface perceives the studied construct as relevant to $R \& D$ and that they are several factors that influence $R \& D$ within the product development phenomena. The study concentrated on issues of R\&D failing to link its outcome to NPD strategy and firm performance which could be the main objective of the R\&D. Wayner (2010) established that consumers often vary highly in their interest and ability to participate in cocreation tasks and that they may participate in the cocreation process for psychological reasons that have remained poorly understood. Frank (2010) investigated how the magnitude of innovation strategy moderates the impact of a model of product development on performance and he noted that firms need to evaluate the extent of the tolls that enable them progress on their product development tools.

Even though there exist a large number of researches that have examined the link between product development strategy and performance, they however fail to include the postulates of a multidisciplinary theoretical work. In 
addition despite the fact that several studies have supported an association between market orientation and profitability, the link between market orientation and innovation based product development appears to be more complex (Martin \& Grbac, 2003; Slater \& Narver, 2000). From the extant theoretical literature, there is need to link market adoption characteristics phenomenon with product development and firm performance. Several conceptual writings suggest that the importance of market orientation for organizational performance depends on environmental conditions (Narver \& Slater, 1990; Gima, 1995). A strong market orientation is required to focus the organization on those environmental events that are likely to influence their ability to increase customer satisfaction relative to competitors (Baker \& Sinkula, 1999). Kohli \& Jaworski (1990), for example suggest that market orientation may not have critical importance in turbulent environments. Technical turbulence moderates customer and competitor orientations' impact upon innovation performance (Narver \& Slater, 1990). Subsequent research shows that the strength of the relationship between market orientation and firm performance is not influenced by the environment (Jaworski \&Kohli, 1993; Gima, 1995). As a result, implementation of a market-oriented strategy and reacting to market feedback may allow a firm to adapt successfully to external environmental changes. However while a strong market orientation may keep a firm on a steady course, alone, it may not necessarily constitute a dominant market position for the firm. Firms with both strong learning and market orientations may be best able to respond to environmental forces through learning that enables innovative and reactive marketplace behaviour (Baker \& Sinkula, 1999).

In view of the state of reviewed empirical work, the authors are of the view that; first there is need to link product development strategy to firm performance and in view of the fact that product development strategy and firm performance may not have a straight forward relationship since there is a possibility of a moderating factor in linking the two variables. Secondly, in essence innovation in new product development processes is boosted by the emerging demand of the customers and the need to meet their demand in order to respond to the fiercer competition. Since competition has a close link with the market, the characteristics of the market that may bring about opportunities for competition in the case of Product Development need consideration through the diffusion process. Thirdly, innovation which results from PD strategy is widely recognized as an important source of sustainable competitive advantage and firm performance, in an ever increasingly changing market environment and hence the need to link product development strategy, market adoption and firm performance. There is no clear explanation as to how PD strategy affects firm performance. There could be other moderating and mediating factors that impact on this relationship.

Finally even though product development strategy is described and analysed in most of the studies, there is need to link this to customer needs and wants, competitive environment and the nature of the market as these are factors that determine the success of the product development strategy. The long term profitability of a firm has been shown to be related to the firm's ability to innovate in the strategy, marketing and economics literatures (For example, Gerosld, Machin \& Van Reenen 1993, Soni, Lilien \& Wilson 1993, Capon, Farley \& Hoenig 1990). In the past, the marketing strategy literature has presented evidence that a firm's strategic orientation as a market-driven company (Day, 1990) is a significant indicator of its performance, including management's perception of the success of new products (Narver \& Slater 1990; Slater \& Narver 1994). These two issues (i.e., innovating and strategic orientation) are not, however, independent.

\section{The Proposed Theoretical Model}

From the observations raised from the theoretical and empirical reviews, this paper proposes an integrated theoretical model to explain the relationship between Product Development strategy and firm performance while providing for the characteristics of the markets. The proposed model is shown in Figure 1. The model proposes several constructs and their relationships. 


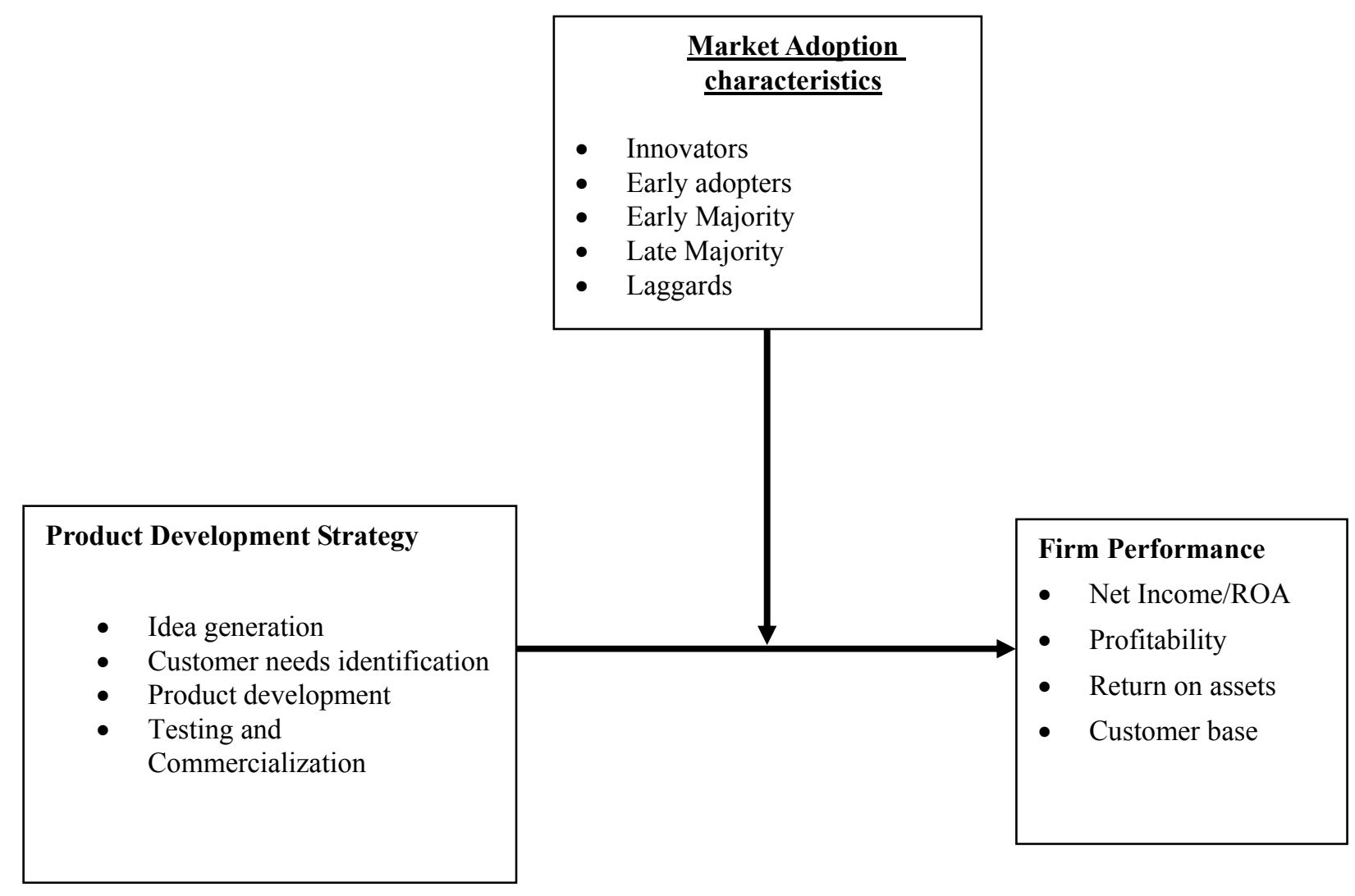

Figure 1. Theoretical model integrating product development strategy, market adoption and firm performance

\subsection{The Role of Product Development Strategy}

From a conceptual point of view, the stage for the whole phenomenon is set by the product development strategy construct which plays the role of the predictor. In this case the anticipated strategic behaviour consisting product development strategy will be triggered by a series of activities that when adopted by the firm will result to relevant positive impact on the performance of the firm.

The product development strategy entails taking a company outside its existing business and a new product is developed for a new or existing market. Developing new products or modifying existing products so they appear new, and offering those products to current or new markets is the key feature of product development strategy. Product development strategy is seen as a competitive tool and can give a firm better performance. In the figure above firm performance is the result of product development strategy. Thus Product development strategy as a tool of competition and may give a firm a better outcome. As seen above performance measures are a result of product development strategy and therefore we should analyse product development strategy in relation to a range of performance measures as proposed above. Under normal conditions, it is expected that a firm invests in a strategy where it will reap benefits that manifests in the forms that reflects the performance indicators thus the paper puts forward the first proposition that;

Proposition One: Firms investing in product development strategy will experience a positive relationship between those product development strategy investments and the emergent firm performance.

\subsection{The Role of Market Adoption}

Even though the relationship between PD strategy and firm performance has been described in a more direct form, yet in real life situation the relationship is far from straight forward in the context of the market which is a recipient 
of the product development strategy and its outcomes. The characteristics of the market and the market adoption process play a key role in determining the success or failure of the product development strategy.

Market adoption entails a cognitive process through which all the consumers pass before actually purchasing any products. Marketing tools may change, the way consumers discover products may change, and consumer behaviours may change, but the 5 stages that make up the market adoption process are likely to remain the same remain the same.

In view of the potential influence of the phenomenon of market adoption process, this paper puts forward the second proposition that;

Proposition Two: Even though PD strategy influences firm performance, this relationship is contingent upon the prevailing characteristics of the market that constrain the product adoption.

\section{Conclusions and Recommendations}

The purpose of this theoretical paper was to review both extant theoretical and empirical literature, identify existing gaps in the phenomenon of the relationship between product development strategy and firm performance and suggesting a theoretical framework providing propositions for filling the identified gaps. The theoretical paper is anchored in the concepts of Igor Ansoff's broad concept of growth strategy which is operationalized using three strategies: integrative growth, intensive growth and diversification growth and secondly diffusion of innovation theory. Extant literature reviewed has identified existing relationships between product development strategy and a firm's performance. This paper adopted a multidisciplinary based approach to propose an integrated theoretical model for explaining factors that influence this relationship.

While this paper contributes towards understanding the linkage between product development strategy and firm performance while integrating market adoption characteristics, it also makes suggestions for future research. First, the paper identifies the weaknesses in existing empirical literature and provides an integrated approach to market adoption characteristics and its influence on product development strategy. The study identifies the need for investigations since this relationship is not direct, assessing the moderating influence of market adoption characteristics, which will not only enhance the conceptual rigour but also enhance understanding the relationship in a more relevant manner. In view of the identified weaknesses, the paper suggests that future research should embrace this integrated model to guide empirical work in less studied contexts to establish the linkage between product development strategy and market adoption characteristics and eventually its influence to firm performance. This in itself creates a future research agenda which aims to answer some critical questions, for example the influence of market adoption characteristics on product development strategy and the relationship between product development strategy and firm performance. Future research is called upon to fill these gaps.

\section{References}

Andreea, N., \& Barr, S. (2014). New Product Development Strategy Implementation Duration and New Venture Performance: A Contingency-Based Perspective. Journal of Management. http://dx.doi.org/10.1177/0149206314549251

Ansoff, I. (1957). Strategies for Diversification. Harvard Business Review, 35(5), 113-124. http://dx.doi.org/10.1177/1086026615595084

Baker, W. E., \& Sinkula, J. M. (1999). The synergistic effect of market orientation and learning orientation on organizational performance. Journal of Academy of Marketing Science, 27(2), 411-427. http://dx.doi.org/10.1177/0092070399274002

Barney, J. B., \& Wright, Ketchen Jr, M.D.J. (2001). The resource-based view of the firm: Ten years after 1991. Journal of Management, 27(6), 411-427. http://dx.doi.org/10.1177/1523422315572651

Booz, A., \& Hamilton. (1982). New Products for the 1980s. New York Times.

Bourgeois, L. J. (1984). Strategic management and determinism. Academy of Management Review, 9, 586-596.

Capon, N., John, U. F., \& Scott, H. (1990). Determinants of Financial Performance: A Meta-Analysis. Management Science, 36(10), 1143-1149. http://dx.doi.org/10.1287/mnsc.38.2.157

Čok, V., Fain, N., Vukašinovic, N., \& Žavbi, R. (2015). Multicultural issues of product development education in virtual teams. International Journal of Engineering Education, 31(3), 863-873. http://dx.doi.org/10.1108/13527590410556827 
Cooper, R. G., \& Kleinschmidt, E. J. (1991). New product processes at leading industrial firms. Industrial Marketing Management, 25(3), 137-147. http://dx.doi.org/10.1108/EJIM-08-2013-0086

Cooper, R., \& Kleinschmidt, E. (1994). Determinants of timeliness in new product development. Journal of Product Innovation Management, 11(5), 381-9. http://dx.doi.org/10.1111/1540-885.1150381

Eisenhardt, K. M., \& Zbaracki, M. J. (1992). Strategic decision making. Strategic Management Journal, 13, 17-37. http://dx.doi.org/10.5465/amr.2015.0094

Freeman, Clark, C., \& Joete, L. (1982). Unemployed and Techinical innovation: A study of long wave and economic development. Pinter, London.

Geroski, P., Steve, M., \& John, V. R. (1993). The Profitability of Innovating Firms. RAND Journal of Economics, 24(2), Summer, 198-211. http://dx.doi.org/10.1016/S0048-7333(96)00903-1

Glaister, K. W. (2008). A causal analysis of formal strategic planning and firm performance. Management Decision.

Hrebiniak, L. G., Joyce, W. F., \& Snow, C. C. (1988). Strategy, structure, and performance. In Snow C. C. (Ed.), Strategy, organizational design, and human resource management (Vol. 3, pp. 3-54). Greenwich, CT: JAI Press.

Hull, F. M. (2004). Innovation Strategy and the Impact of a Composite Model of Service Product Development on Performance. Journal of Service Research, 7(2), 167-180. http://dx.doi.org/10.1177/1094670504268452

Jaworski, B., \& Kohli, A. (1996). Market Orientation: Review, Refinement and Roadmap. Journal of Market Focused Management.

Kohli, A., \& Jaworski, B. J. (1990). Market Orientation: The Construct, Research Propositions and Managerial Implications. Journal of Marketing Research, 54, 1-19. http://dx.doi.org/10.1016/0167-8116(92)90019-H

Kotler, P. (1991). Marketing management: Analysis, Planning, Implementation and Control (7th ed.). Englewood Cliffs, NJ: Prentice-Hall.

Krishnan, V., Ulrich, M., \& Karl. (2001). Product development decisions: A review of the literature. Management science, 47(1), 1-21. http://dx.doi.org/10.1287/mnsc.47.1.1.10668

Miller, D. (1987). Strategy making and structure: Analysis and implication for performance. Academy of Management Journal, 30(7), 32: http://dx.doi.org/10.2307/255893

Narver, J. C., \& Slater, S. F. (1990). The Effect of a Market Orientation on Business Profitability. Journal of Marketing, 20-35. http://dx.doi.org/10.2307/1251757

Ngulumi, P. M. (2013). Effect of Bank innovations on financial performance of commercial banks in Kenya. Nairobi: Jomo Kenyatta University of Agriculture and Technology.

Rogers, E. (1995). Diffusion of Innovations. NewYork: Free Press.

Soni, Praveen K., Gary, L. L., \& David, T. W. (1993). Industrial Innovation and Firm Performance: A Re-conceptualization and Exploratory Structural Equation Analysis. International Journal of Research in Marketing, 10, 365-380. http://dx.doi.org/10.1016/0167-8116(93)90019-U

Sook, F. F., May, C., \& Ramayah, J. (2014). New Product Development and Performance in the Banking Industry. Asia-Pacific Journal of Management Research and Innovation, 10, 305-321. http://dx.doi.org/10.1108/03090569310045870

Wayne, D. H., Manfred, K., \& Katrin, K. (2010). Customer Relationship Management and Company Performance-The Mediating Role of New Product Performance. Journal of the Academy of Marketing Science, 38. http://dx.doi.org/10.1509/jmkg.68.2.114.27788 